\title{
MENINGKATKAN KETERAMPILAN MENGGUNAKAN SOFTWARE R SEBAGAI SOLUSI UNTUK MENINGKATKAN INOVASI PEMBELAJARAN BAGI GURU-GURU MATEMATIKA SMA DAN SMK DI JAKARTA TIMUR
}

\author{
Widyanti Rahayu ${ }^{1)}$, Siti Rohmah Rohimah ${ }^{2)}$ \\ Jurusan Matematika Fakultas MIPA Universitas Negeri Jakarta
}

\begin{abstract}
ABSTRAK
Kondisi yang dialami oleh banyak guru matematika antara lain yaitu kurangnya inovasi dalam pembelajaran matematika. Guru wajib memiliki kualifikasi akademik, kompetensi, sertifikat pendidik, sehat jasmani, dan rohani, serta memiliki kemampuan untuk mewujudkan tujuan pendidikan nasional.untuk menjamin keterlaksanaan tugasnya secara professional. Untuk meningkatkan kompetensi guru-guru khususnya guru-guru di Sekolah Menengah Atas dan Sekolah Menengah Kejuruan perlu diberikan pelatihan-pelatihan software yang menunjang tugas utamanya sebagai pendidik. Salah satu software yang berguna untuk pembelajaran matematika diantaranya Software $R$. Software $R$ dapat digunakan untuk menjelaskan banyak topik dalam matematika antara lain: masalah aritmatika, geometri, maupun aljabar. Sofware $R$ juga dapat digunakan guru untuk membantu evaluasi pembelajaran maupun untuk mengolah data penelitian. Melalui pelatihan software $R$ bertujuan agar guru mampu berinovasi untuk meningkatkan kemampuan dan kreativitas mengajar matematika guruguru di Sekolah Menengah Atas dan Sekolah Menengah Kejuruan di Jakarta Timur. Feedback dari kegiatan pelatihan yang diselenggarakan, peserta memberikan respon positif terhadap pelatihan tentang Software R.
\end{abstract}

Kata kunci : Pelatihan, Software R, Inovasi Pembelajaran, Guru

\section{PENDAHULUAN}

A. Latar Belakang Masalah

Matematika masih menjadi pelajaran yang cukup ditakuti oleh siswa SMK. Hal ini terlihat dari hasil UN para siswa, nilai matematika termasuk mata pelajaran yang nilainya lebih kecil dibandingkan dengan nilai untuk mata pelajaran lainnya. Dalam mengajarkan Matematika bagi siswa SMK perlu bantuan media visual karena Matematika adalah pelajaran yang abstrak. Hal ini sesuai dengan Undang-undang No. 20 Tahun 2003, Peraturan Pemerintah No.19 tahun 2005, dan Peraturan Menteri No. 24 tahun 2007 yang mengharuskan penggunaan TIK dalam proses pembelajaran di sekolah. Banyak sarana TIK yang dapat digunakan sebagai media pembelajaran, misal kalkulator, komputer dan softwarenya, dan internet.Software-software yang berguna untuk pembelajaran matematika diantaranya $\mathrm{R}$, MAPLE, MATLAB, GEOGEBRA, dan SPSS.

Software $\mathrm{R}$ dapat digunakan untuk menjelaskan banyak topik dalam matematika baik masalah aritmatika, geometri, maupun aljabar. Misalnya penyelesaian sistim persamaan linier, jumlah deret, persamaan kuadrat dan sekaligus menampilkan grafiknya dari berbagai sudut pandang. Sehingga apabila guru dan siswa menguasai software $\mathrm{R}$ maka keabstrakan pelajaran matematika dapat dikurangi sehingga siswa akan lebih mudah memahami konsepkonsep matematika yang diajarkan guru.

Pusat pelatihan hanya difokuskan pada gugus wilayah I Jakarta Timur. Tempat gugus tersebut mengadakan musyawarah bertempat di pusat rayon yang berlokasi SMKN 26 Jakarta Timur. Pada umumnya guru-guru matematika sering mendiskusikan permasalahan yang terkait dengan kegiatan pembelajaran matematika. wadah ini sangat bagus sebagai tempat curahan hati para guru dalam menyelesaikan masalah yang muncul.

Adapun yang menjadi perhatian kita adalah terkait dengan kurangnya inovasi dalam pembelajara matematika. Mengingat tugas guru sebagai pendidik profesional dengan tugas utama mendidik, mengajar, membimbing, mengarahkan, menilai, dan mengevaluasi peserta didik pada berbagai jenjang dan jenis pendidikan formal. Selain itu untuk menjamin keterlaksanaan tugasnya yang utama tersebut, 
guru wajib memiliki kualifikasi akademik, kompetensi, sertifikat pendidik, sehat jasmani, dan rohani, serta memiliki kemampuan untuk mewujudkan tujuan pendidikan nasional. Untuk meningkatkan kompetensi guru-guru khususnya guru-guru di Sekolah Menengah Atas perlu diberikan pelatihan-pelatihan yang menunjang tugas utamanya sebagai pendidik. Dengan memberikan pelatihan software $\mathrm{R}$ diharapkan akan meningkatkan kemampuan dan kreativitas mengajar matematika guru-guru di Sekolah Menengah Atas atau Sekolah Menengah Kejuruan di Jakarta Timur.

Pada kenyataannya, banyak guru di SMK di Jakarta Timur menginginkan pengetahuan tentang inovasi terbaru dalam pembelajarannnya. Banyak guru yang ingin mengintegrasikan antara matematika dengan komputer. Hal ini memiliki tujuan agar siswa tertarik untuk belajar matematika dengan menyenangkan. Pada kenyataannya banyak guru yang memiliki keterbatasan penguasaan software. Padahal mereka yakin dengan pembelajaran matematika berbasis computer dapat membantu siswa dalam meningkatkan pemahaman matematika dengan mudah dan mampu meningkatkan kreativitas bagi siswanya.

Selain itu, paradigma mereka selalu berpikir bahwa matematika dianggap pelajaran yang sulit untuk dipelajari, sehingga banyak siswa yang tidak menyukai pelajaran matematika. Biasanya guru cenderung untuk menciptakan suasana pembelajaran yang konvensional yang hanya mengajarkan konsep dan rumus-rumus matematika. Hal ini membuat suasana belajar siswa tidak bergairah dan membosankan. Sementara, siswa sekarang ini sangat menyukai berinteraksi dengan komputer, sehingga guru harus meningkatkan kemampuannya dalam mengajar dengan menambahkan penggunaan software dalam membantu mengajar konsep, rumus, dan penerapannya dalam kehidupan sehari-hari. Pembelajaran di kelas yang disertai penggunaan software yang terintegrasi dapat memotivasi siswa dalam meningkatkan minat belajar matematika dan meningkatkan kreativitas siswa.

Universitas Negeri Jakarta sebagai salah satu Perguruan Tinggi di DKI Jakarta memiliki tanggungjawab untuk membantu melaksanakan program pemerintah dalam mengembangkan inovasi pembelajaran di sekolah. Sebagai bentuk pelaksanaan salah satu misi UNJ yaitu mengembangkan berbagai bentuk pengabdian kepada masyarakat di bidang ilmu, teknologi, dan seni yang berdaya guna dan berhasil guna, jurusan matematika bermaksud mengadakan suatu kegiatan pelatihan bagi guru SMA dan SMK di Jakarta Timur. Pelatihan tersebut dimaksudnya untuk memberi pengetahuan dan pengalaman praktek tentang Sofware R.

Pelatihan khususnya diadakan untuk Guru SMA dan SMK di lingkungan dinas pendidikan Jakarta Timur dengan pertimbangan: (1) Penting sekali bagi guru SMK mengenal software R yang tidak berbayar untuk membantu mengembangkan kompetensi guru (2) Jakarta Timur dipilih karena lokasi terdekat dari UNJ, sehingga dari tempat yang terdekat pelatihan akan mudah dilaksanakan untuk pertama kalinya.

\section{B. Perumusan Masalah}

Banyak siswa SMA dan SMK yang memiliki kesulitan dalam menyelesaiakan persoalan matematika di sekolah. Hal ini mendorong guru untuk senantiasa melakukan inovasi dalam pembelajaran matematika. Selain itu, zaman sekarang ini adalah zaman yang canggih dan melek teknologi, sehingga pembelajaran yang yang konvensional membuat anak tidak tertantang bahkan tidak tertarik untuk belajar. Banyak guru yang memiliki keterbatasan penguasaan software. Padahal dengan berbantuan software dapat meningkatkan minat siswa untuk belajar matematika. Selain itu, banyak guru yang tidak mengenal software yang free seperti $\mathrm{R}$ dan mereka juga tidak menyadari bahwa software sangat bermanfaat dalam pelajaran matematika bahkan sangat mudah dipelajari.

Untuk menanggulangi permasalahan tersebut maka guru perlu melakukan inovasi dalam pembelajaran matematika. Banyak inovasi yang bisa dilkukan jika guru telah menguasai software R. Melalui Pemanfaatan software R sebagai bahan untuk simulasi dalam pembelajaran matematika, sehingga siswa 
merasa termotivasi belajar matematika. Selain itu, dengan $\mathrm{R}$ guru dapat meningkatkan kualitasnya dalam melakukan penelitian untuk kepentingan evaluasi siswa maupun untuk kepentingan kenaikan pangkat.

Berdasarkan uraian di atas, dapat diidentifikasi beberapa masalah, yaitu:

1. Apakah peserta pelatihan memahami materi yang disampaikan tentang Software R?

2. Bagaimana aktivitas peserta pelatihan dalam mengikuti kegiatan pelatihan Software R?

\section{Tujuan}

Kegiatan pengabdian ini memiliki tujuan sebagai berikut:

1. Memberikan pengetahuan bagi peserta pelatihan tentang Software $\mathrm{R}$ dan manfaatnya bagi guru.

2. Memberikan solusi bagi peserta pelatihan agar mau menerapkan dalam pembelajarannya di kelas, sehingga guru mampu mengatasi kesulitan dalam pembelajaran matematika di sekolah. Selain itu, peserta pelatihan diberikan keterampilan untuk mengevaluasi pembelajaran dan mampu meneliti menggunakan software R.

\section{Manfaat}

Program pengabdian kepada masyarakat ini diharapkan dapat memberikan manfaat kepada:

1. Memberikan solusi secara tidak langsung kepada siswa, karena setelah pelatihan ini diharapkan guru mau menerapakan dalam pembelajarannya di kelas, sehingga guru mampu mengatasi kesulitan dalam pembelajaran matematika.

2. Meningkatkan kompetensi guru karena melalui software $\mathrm{R}$ dapat digunakan untuk mengevaluasi pembelajaran dan membantu mengolah data penelitian.

3. Meningkatkan kualitas sekolah, karena melalui pelatihan ini dapat meningkatkan kompetensi bagi guru matematika yang ada di lingkungan Jakarta Timur.

\section{TINJAUAN PUSTAKA}

A. Pengenalan Bahasa $\mathbf{R}$

Bahasa R merupakan versi sumber terbuka (open-source) dari bahasa pemrograman $\mathrm{S}$ (Azola dan Harrel, 2006). Versi komersial yang berbasis bahasa $\mathrm{S}$ adalah $\mathrm{S}$ plus. Bahasa $\mathrm{R}$ memiliki kemampuan yang tidak kalah dangan paket-paket program pengolahan data komersial bahkan dalam beberapa hal kemampuannya lebih baik. Perbandingan R khususnya terhadap SAS dibahas secara rinci oleh Azola dan Harrel (2006). Bahasa R mendapat sambutan yang baik dari kalangan statistikawan di seluruh dunia, sayangnya di Indonesia belum banyak dikenal.

\section{B. Cara Kerja Bahasa R}

Verzani (2002) mengemukakan bahwa keuntungan-keuntungan yang diperoleh bila menggunakan bahasa $\mathrm{R}$ untuk pengolahan data dan statistik antara lain: $\mathrm{R}$ dapat diakses gratis dan dapat dijalankan pada berbagai sistem operasi (UNIX, Windows, Macintosh), sintaksnya mudah dipelajari dan memiliki banyak sekali fungsi-fungsi statistik terpasang. Disamping keuntungan tersebut Verzani (2002) juga mengumukakan kelemahan utama bahasa $\mathrm{R}$ adalah tidak adanya dukungan komersial. Azola dan Harrel (2006) memberikan perbandingan rinci atas kemampuan bahasa $\mathrm{R}$ terhadap program komersial SAS. S-Plus sebagai "kembaran" komersial dari bahasa R memiliki antar muka yang lebih baik, tetapi berjalan sedikit labih lambat dari pada $\mathrm{R}$.

Sofware R merupakan sebuah paket dan sekaligus bahasa pemrograman untuk analisis data dan grafik. $\mathrm{R}$ merupakan bahasa pemrograman tingkat tinggi (hight level programming). $\mathrm{R}$ dapat digunakan secara interaktif sehingga hasil perhitungan segera dapat dilihat, tetapi apabila perhitungannya kompleks maka perintah-perintah $\mathrm{R}$ ditulis lebih dahulu dalam text editor, kemudian dipanggil dengan fungsi source. Program R dapat di akses gratis di internet di http://www.r-project.org/. 
dan sebagaimana halnya program open source, $\mathrm{R}$ dirancang secara voluntary oleh ahli-ahli statistik dan pemrograman di seluruh dunia, sehingga perkembangannya sangat pesat, Versi R terakhir ketika tulisan ini dibuat adalah 2.4.1. $\mathrm{R}$ juga dilengkapi dengan package (add-in) yang memberikan kemampuan tambahan, misalnya perhitungan teknik-teknik statistik yang canggih,interface dan lain-lain. Packages ini juga dapat diakses gratis. Secara periodik muncul package- package baru yang menarik yang dapat dipilih sesuai kebutuhan. Semua package ini dapat diperoleh gratis di http://cran.r-project.org/.

\section{Skema Kerja Bahasa R}

Setelah $\mathrm{R}$ terinstal pada komputer maka dapat diakses melalui shortcut atau menu start. Prompt default ">” mengindikasikan bahwa R menunggu perintah yang diberikan, baik berupa fungsi maupun objek lain. $\mathrm{R}$ merupakan suatu bahasa berorientasi objek, artinya bahwa variabel, data, fungsi, hasil dan sebagainya, disimpan dalam memori aktif komputer dalam bentuk objek dan mempunyai sebuah nama. Pengguna dapat mengenakan aksi terhadap objek-objek tersebut melalui suatu operator (aritmatika, logika, dan perbandingan) dan fungsi (functions). Fungsi itu sendiri juga merupakan suatu objek. Penamaan terhadap objek bersifat case sensitive (membedakan huruf besar dan huruf kecil). Jadi X dan x merupakan objek yang berbeda.

Argumen suatu fungsi dalam $\mathrm{R}$ juga merupakan suatu objek (“data”, formula, expresi, dan sebagainya). Beberapa fungsi menyediakan nilai default dari argumennya, nilai ini dapat diubah oleh penggunanya dengan options tertentu. Beberapa fungsi tidak membutuhkan nilai argumen dalam menjalankan perintahnya, hal ini dapat terjadi karena ada dua kemungkinan

1) semua argumennya mempunyai nilai default (karenanya dapat diubah dengan options). Jadi dalam mengeksekusi fungsi tersebut tidak perlu memasukkan nilai argumen, karena fungsi akan menggunakan nilai default sebagai nilai argumen. 2) tidak ada argumen yang didefinisikan sebelumnya pada fungsi tersebut.

Objek-objek R (termasuk fungsi) dikemas dalam bentuk add-ins yang oleh $\mathrm{R}$ disebut dengan package. Pada saat $\mathrm{R}$ dipanggil pertama kali, maka ada tujuh package yang dipanggil dan disimpan dalam memori aktif.

Semua aksi pada $\mathrm{R}$ dilakukan dengan memanipulasi objek yang tersimpan pada memori aktif komputer: tanpa menggunakan file temporary. Pengguna mengeksekusi fungsi, yang mana nilai argumen akan menentukan hasilnya (dapat juga berupa suatu grafik). Hasil eksekusi ini diperagakan secara langsung pada layar, disimpan pada sebuah objek yang dapat diberi nama tertentu, atau ditulis pada disk (khusunya grafik). Oleh karena hasil itu sendiri merupakan sebuah objek, maka objek ini dapat merupakan nilai argumen (data) bagi fungsi lain untuk selanjutnya dieksekusi.

Sofware $\mathrm{R}$ bekerja berdasarkan jenis struktur datanya. Struktur data paling sederhana adalah vector. Vektor dibuat dengan fungsi c, hasilnya disimpan dalam suatu objek. Selain itu fungsi read.table digunakan untuk membaca data dalam format ascii (txt, dat). Fungsi ini tersedia pada package base.

\section{Tampilan Grafik Dengan $\mathbf{R}$}

Sofware R menyediakan kemampuan yang kaya untuk visualisasi grafik (Rossiter, 2006). Tersedia dua sistem grafik: sistem base (terdapat dalam package graphics, yang dipanggil secara default ketika memulai R) dan sistem trellis (tersedia dalam package lattice). Disamping kedua sistem tersebut, terdapat berbagai package tambahan yang memperkaya kemampuan grafik R, antara lain:misc3d (berbagai plot 3 dimensi), rgl (sistem device untuk visualisasi grafik 3 dimensi), scatter plot 3d (scatter plot 3 dimensi) dan beberapa package lain yang tidak ditujukan khusus untuk grafik seperti tseries, menyediakan kamampuan untuk menampilkan grafik-grafik deret waktu. 


\section{MATERI DAN METODE}

\section{A. Kerangka Penyelesaian Masalah}

Merujuk kepada rumusan masalah yang telah teridentifikasi sebelumnya yaitu Apakah peserta pelatihan memahami materi yang disampaikan tentang Software R? Serta bagaimana keadaan peserta pelatihan dalam mengikuti kegiatan pelatihan Software R? Untuk menjawab pertanyaan ini maka perlu analisis lebih mendalam situasi di Sekolah. Berikut ini situasi yang mungkin dijumpai di sekolah tingkat SMA dan SMK di Jakarta Timur:

1) Belum mengenal dan memahami software yang open source.

2) Masih kesulitan dalam mengevaluasi secara mudah menggunakan sofware yang free terkait dengan evaluasi pembelajaran maupun mengolah data penelitian.

Dibatasi oleh constraint waktu pelaksanaan kegiatan P2M yang hanya satu hari, dan mempertimbangkan tingkat kesulitan dalam memahami Software $\mathrm{R}$ serta keterbatasan skill ICT yang dimiliki oleh para peserta maka solusi yang tim pengabdi tawarkan adalah dengan memberikan kegiatan pelatihan khusus materi yang diperlukan saja yaitu konsep vektor, matriks, dan analisis data sederhana yang meliputi analisis deskriptif, analisis regresi, dan uji t.

\section{B. Khalayak Sasaran}

Sasaran utama kegiatan ini adalah guru matematika SMA dan SMK di wilayah I Jakarta Timur. Terdapat total 26 undangan yang dikirimkan ke sekolah-sekolah yang terdapat di lingkungan SMA dan SMK di wilayah I Jakarta Timur.

\section{Materi Penerapan IPTEK}

Metode yang digunakan pada program ini adalah teori, praktek, dan diskusi. Teori diberikan dalam bentuk pembelajaran di kelas. Praktek dilaksanakan masing-masing di dalam kelas dengan menyelesaikan latihan yang telas disiapkan oleh pengajar.
Langkah-langkah kegiatan Pelatihan Software R untuk guru SMA dan SMK wilayah I Jakarta Timur adalah sebagai berikut:

1. Menyebarkan angket kepada peserta sebelum kegiatan pelatihan.

2. Nara sumber mempresentasikan tentang pentingnya penguasaan sofware $\mathrm{R}$ bagi guru matematika di sekolah SMK dan SMA.

3. Memberikan materi tentang vektor, matriks, dan analisis data.

4. Melalui diskusi, peserta menanyakan tentang kesulitan-kesulitan dalam membuat program-program di Software R.

5. Peserta secara mandiri diberi tugas untuk menjalankan program dengan kasus-kasus yang berbeda.

6. Nara sumber dan tim membantu peserta yang masih kesulitan dalam mengerjakan tugas mandiri.

7. Beberapa guru mempresentasikan hasil kerjanya.

Menyebarkan angket kepada peserta sesudah kegiatan pelatihan.

\section{HASIL DAN PEMBAHASAN}

Kegiatan P2M dilaksanakan dengan acara tatap muka dan praktek pembuatan program. Kegiatan pelatihan utamanya menjelaskan mengenai praktik membuat program vektor, matriks, dan analisis data berjalan baik dan lancar. Pertemuan tatap muka dengan metode ceramah dan diskusi, dilanjutkan dengan latihan/praktek membuat program dengan kasus-kasus yang berbeda yang sering ditemui dalam pembelajaran maupun penelitian di kelas. Kegiatan dilaksanakan sehari yaitu pada hari Rabu 7 Oktober 2015 di Laboratorium Matematika UNJ Gedung Dewi Sartika Lantai 5 pukul 08.30-13.30. Peserta yang hadir berjumlah 18 orang.

Program pengabdian pada masyarakat berupa pelatihan Sofware $\mathrm{R}$ yang terdiri dari materi vektor, matriks, dan analisis data sudah 
dilaksanakan. Kegiatan ini diharapkan dapat menambah pengetahuan, keterampilan, sehingga kompetensi yang dimiliki guru meningkat. Guru akan lebih semangat untuk mengembangkan profesinya diantaranya melakukan inovasi pembelajaran menggunakan Software $\mathrm{R}$ dan melakukan penelitian untuk melakukan evaluasi pembelajaran maupun untuk kebutuhan pangkat. Hasil pelatihan ini diharapkan bermanfaat bagi sekolah, sehingga proses belajar mengajar menjadi lebih menarik.

\section{A. Aktivitas Peserta Pelatihan}

Keaktifan peserta pelatihan dinilai melalui indikator kesungguhan, aktif bertanya, kedisiplinan, dan kerja sama. Hampir 75\% peserta pelatihan aktif bertanya, bersungguhsungguh dalam mengikuti pelatihan, disiplin dalam mengikuti kegiatan pelatihan, kerjasama yang baik antara para peserta dengan tim pengabdi.

Kedisiplinan dari peserta pelatihan juga terbukti dari ketepatan waktu kehadiran, tertib mengikuti materi pelatihan, serta disiplin menunggu pulang setelah selesai seluruh rangkain acara pelatihan. Selain itu, peserta pelatihan juga memiliki semangat yang tinggi untuk mengetahui dan belajar Software $\mathrm{R}$ yang cukup tinggi, terlihat dari banyaknya pertanyaan pada saat sesi tanya jawab. Selain itu, tampak dari peserta pelatihan serius mengerjakan latihan yang diberikan.

\section{B. Daftar Peserta Pelatihan}

Peserta yang menghadiri undangan pelatihan total berjumlah 18 orang guru SMK dan SMA di wilayah 1 Jakarta Timur. Dilihat dari sisi perwakilan sekolah, terdapat 11 sekolah swasta dan sisanya perwakilan dari sekolah negeri.

\section{Hasil Survey/Feedback Peserta}

Survey dilakukan terhadap peserta pelatihan sebelum dan setelah kegiatan pelatihan. Berikut adalah hasil surveynya.

\section{Sebelum pelatihan}

a. Frekuensi penggunaan software dalam pembelajaran atau penelitian: Berdasarkan hasil survey diketahui bahwa mayoritas responden hanya menggunakan software 1 atau 2 kali dalam pembelajaran atau penelitian.

b. Jenis penelitian yang sudah dilakukan:

Ketika ditanyakan jenis penelitian apa yang sudah pernah dilakukan oleh responden, mayoritas menjawab penelitian PTK (10 orang), kualitatif (5 orang), kuantitatif (3 orang), dan 1 orang lainnya.

c. Jenis software yg digunakan dalam penelitian atau pembelajaran:

Jenis software yang digunakan dalam penelitian adalah mayoritas menggunakan excel (12 orang), SPSS (6 orang), sisanya belum pernah. Software $\mathrm{R}$ belum pernah digunakan oleh peserta pelatihan sebelumnya.

\section{Sesudah pelatihan}

Berdasarkan angket yang diberikan pada peserta pelatihan setelah memperoleh pelatihan, diperoleh hasil yang sangat antusias dan umpan balik yang positif terhadap manfaat yang diterima. Hal ini terbukti dari jawaban mereka yang menjawab 100 persen mau menggunakan Software $\mathrm{R}$ dalam pembelajaran atau penelitian. Selain itu, peserta pelatihan menjawab 100 persen bahwa mereka akan menggunakan Software $\mathrm{R}$ untuk mengevaluasi hasil pembelajaran siswa. Peserta pelatihan juga menjawab 100 persen bahwa pelatihan software $\mathrm{R}$ sangat bermanfaat bagi mereka. Selain itu kesan, kritik, dan saran yang diberikan peserta pelatihan adalah sebagai berikut:

a. Terhadap materi pelatihan : symbolsimbol supaya lebih jelas, contohcontoh ditambah, diberi simulasi, diberi warna-warna, dan ditambah interpretasi yang lebih detail.

b. Instruktur : sudah cukup bagus dan komunikatif

c. Acara : waktu ditambah, dapat dilanjutkan di lain waktu 


\section{Faktor Pendukung dan Penghambat}

Faktor-faktor yang mendukung kegiatan pengabdian ini terlaksana diantaranya:

1. Rekan mitra, guru-guru SMK dan SMA di wilayah I Jakarta Timur sangat kooperatif dalam membantu terlaksananya acara khususnya kehadiran ke tempat pelatihan tepat waktu dan tertib dalam proses pelaksanaan pelatihan.

2. Undangan tersebar dengan baik dan respon dalam menanggapi undangan cukup baik.

3. Bantuan asisten mahasiswa yang diperbantukan sebagai asisten pengabdi sangat mendukung.

4. Kebutuhan tentang penggunaanSoftware $\mathrm{R}$ tepat sasaran

Tim pengabdi menemukan sejumlah kendala teknis selama perjalanan awal persiapan hingga terlaksananya pengabdian. Namun kendala utama yang dihadapi adalah pendanaan yang diterima terlalu minim untuk dapat lebih kreatif/bermanfaat selama kegiatan pengabdian. Selain itu, kurangnya kreatifitas tim pengabdi dalam mencari sumber dana mandiri.

\section{KESIMPULAN DAN SARAN}

\section{A. Kesimpulan}

1. Topik kegiatan pengabdian cukup tepat sasaran dan sesuai kebutuhan.

2. Respon dari perwakilan sekolah cukup baik, dan berpotensi untuk ditindak lanjuti.

\section{B. Saran}

1. Waktu pelaksanaan pelatihan untuk topik pelatihan Software $\mathrm{R}$ setidaknya full day training

2. Diperlukan follow up terhadap peserta yang memiliki motivasi besar untuk belajar, salah satunya melakukan workshop lanjutan khususnya penggunaan Software $\mathrm{R}$ untuk analisis data lanjutan.

\section{DAFTAR PUSTAKA}

Maindonald, J.H. (2001). Using R for Data Analysis and Graphics An Introduction. Australian National University. http://mirror.aarnet.edu.au/pu b/CRAN.

Owen, W.J. (2006). The R Guide. Department of Mathematics and Computer Science, University of Richmond. http://www.mathc.richmond.edu/ wowe n/TheRGuide.pdf.

http://rianprestasi.blogspot.com/2011/04/modulsoftware-r.html

Suhartono. 2008. Analisis Data Statistik dengan

R. http://bahasa r.blogspot.com/2008/12/ manipulasi-data-dan-grafikmenggunakan.html 